paign=dental-volunteer-abroad-medical-mission-trips-dentists-students https://onlinelibrary.wiley.com/doi/full/10.1111/j.1875-595X.2011.00035.x

9. Somaraj V. Smiles for Life: Model for Child Oral Health Promotion A Proposal / V.Somaraj, R.P.Shenoy, G.S.Panchmal, P.Jodalli, L.Sonde //Int J Oral Health Med Res. - 2015. - Vol. 2(3). - 85-87.

10. Ukrainian Social Academy [Електронний ресурс]. - Режим доступу: https://social-academy.com.ua/

11. Vikram P.A. Public Private Partnership'- Public Private Partnership: The New Panacea in Oral Health / P.A.Vikram // Advances in Dentistry \& Oral Health. - 2018. - №8 (2). - P. 39-42. DOI: 10.19080/ADOH.2018.08.555734. - $\quad$ Avalaible from: https://juniperpublishers.com/adoh/pdf/ADOH.MS.ID.555734.pdf

DOI https://doi.org/10.30525/978-9934-26-045-2-2

\title{
ДЕРЖАВНА ПІДТРИМКА РОЗВИТКУ ГРОМАДЯНСЬКОГО СУСПІЛЬСТВА: УМОВИ, ФАКТОРИ, НАПРЯМИ
}

\author{
Волинець С. C. \\ начальник управління організаційної роботи апарату \\ Дніпропетровської обласної державної адміністрації \\ м. Дніпро, Украӥна
}

Становлення та розвиток громадянського суспільства неможливі без сприяння з боку держави та цілеспрямованої державної підтримки. Остання, у свою чергу, потребує розуміння умов та факторів, що впливають на цей процес.

Так, до ключових суспільних явищ та процесів, необхідних для розвитку громадянського суспільства, слід, насамперед, віднести:

I. Бажання влади та політичної еліти сприяти розвитку громадянського суспільства, а також їх готовність до співпраці з громадськістю. Для влади це нелегкий вибір, адже він, з одного боку, дозволяє ій використовувати потенціал громадськості, поклавши на неї виконання завдань державного, регіонального і місцевого розвитку, а 3 іншого - створює певні обмеження, робить іiі підзвітною та підконтрольною громадськості, позбавляе самостійності в ухваленні рішень. Підтримка розвитку громадянського суспільства грунтується на 
сприйнятті владою громадян як партнерів, а не опонентів, усуненні бар'єрів у спілкуванні між ними, здатності представників влади чути і розуміти громадян.

II. Наявність якісної, ефективної та цілісної нормативно-правової бази, що регулює форми, механізми й інструменти взаємодії влади і громадськості, повноваження і діяльність окремих громадян та їх об’єднань, функціонування інститутів прямої демократії тощо. При цьому, слід врахувати, що на правове регулювання розвитку громадянського суспільства впливає форма державного устрою. Якщо в унітарних державах правове регулювання $є$ однаковим на всій території, то у федеративних державах певні аспекти в різних адміністративно-територіальних одиницях можуть відрізнятися [3, с. 112].

III. Достатню компетентність представників громадськості та органів влади. Громадяни повинні володіти певним комплексом знань, вмінь і навичок, що дозволять правильно використовувати надані права, можливості й інструменти для громадської активності та впливу на владу. Представники влади повинні мати високий рівень правової культури і компетентності, бути готовими впроваджувати практики належного врядування, реагувати на суспільні пріоритети, ефективно застосовувати нові принципи і методи роботи 3 громадськістю. Оскільки розвиток громадянського суспільства передбачає взаємно відповідальні впливи держави і громадськості, то кожна зі сторін цієї взаємодії повинна, у тому числі, знати та розуміти особливості функціонування (правила і стандарти роботи) партнера [6, с. 25].

IV. Наявність у суспільства «сприятливого» громадянського менталітету, що являє собою складову національного менталітету, сукупність спільних для громадян певної країни способів мислення, за допомогою яких встановлюються причинно-наслідкові зв'язки щодо важливих загальнодержавних суспільних та політичних процесів i подій [5, с. 124]. Дана умова є визначальною, оскільки не всі ментальні риси й особливості прийнятні для громадянського суспільства. Так, скажімо, небажання брати на себе відповідальність, індиферентність та соціальна інертність, патерналізм і тяжіння до сильної руки перешкоджають його розвитку або, взагалі, унеможливлюють його існування.

Щоб громадянське суспільство мало перспективи, громадянський менталітет повинен складатися зі світоглядних засад, особливостей мислення та світосприйняття, моральних норм, цінностей та принципів, які обумовлюють розкріпачення етатичної свідомості, активну громадянську позицію і поведінку людей, спонукають до дотримання 
діючих законів, трансформації суспільно-політичної реальності, тісних відносини між людьми тощо.

Громадянський менталітет, як і менталітет, в цілому, історично мінливий, динамічний, гнучкий та може змінюватись в процесі зміни поколінь. Ці зміни нічим і ніким не гарантуються, не відбуваються самі собою, вимагають зусиль і можуть тривати століттями під впливом різноманітних факторів: культурних, історичних, релігійних, соціальних, географічних, природо-біологічних тощо. Багато в чому вони залежать від освіти, яку деякі філософи (Г. Гегель, Д. Юм, Т. Пейн) вважають шляхом людини до громадянського суспільства [1, c. 232].

Слід також звернути увагу на те, що розвиток громадянського суспільства у різних країнах протікає по-різному, що пов'язано 3 такими факторами, як:

a) тип і темпи зміни системи (чим швидше руйнується система, тим швидше розвивається громадянська активність; чим довше формуються політичні та державні інститути, тим інтенсивніше розвивається громадянське суспільство);

b) культурні традиції і ступінь суспільної самоорганізації (чим вони більш розвинені, тим швидше відбувається формування громадянського суспільства);

с) рівень соціально-економічного розвитку (чим більш розвинена країна, тим вищий у ній рівень громадської самоорганізації та структурування; проте позитивний вплив економічних факторів може бути знівельований відсутністю чи нерозвиненістю культурних традицій) [4, с. 83-84].

Отже, розвиток громадянського суспільства залежить як від об'єктивних (соціально-економічна ситуація в державі, темпи суспільнополітичних змін, стан нормативно-правової бази тощо), так і суб'єктивних (політична воля влади та панівної еліти, менталітет і культурні традиції суспільства тощо) факторів, явищ та процесів. Другі, частіше за все, $є$ більш значимими, важливими та неминуче детермінують зміни об'єктивних факторів. Проте, як одні, так й інші повинні однаковою мірою враховуватись під час розробки і впровадження заходів зі сприяння розвитку громадянського суспільства, визначення напрямів та шляхів їх реалізації.

Крім того, громадянське суспільство потребує сильної влади. Не йдеться про поширення впливу влади на всі сфери життя суспільства або контролю за діяльністю та активністю громадян. Мається на увазі влада, що ефективно і повною мірою виконує свої обов'язки, $є$ 
гарантом існування громадянського суспільства, забезпечує сприятливі умови його розвитку.

Завдання влади - допомогти громадянському суспільству «підвестися на ноги» [2, с. 349], сформувавши державний устрій, що враховує потреби та підтримує повноцінний розвиток кожної людини, дозволяє громадянам дбати про власні інтереси, забезпечує їх засобами i механізмами впливу на владу, стимулює суспільно-корисну i соціально-значущу громадську активність, сприяє самоорганізації суспільства, розкриттю і реалізації ініціатив і потенціалу громадян. Така роль влади, на думку вчених, проявляється у таких публічноправових зрізах:

нормативно-правовому (формування належної нормативно-правової бази, встановлення загальних та зрозумілих «правил гри» тощо);

- організаційно-правовому (створення механізмів захисту i реалізації прав, простих і зрозумілих правил легалізації громадських об’єднань тощо);

- інституціональному (створення окремої державної структури, метою якої $є$ формулювання та реалізація засад відповідної державної політики тощо);

- правозахисному (створення системи захисту прав й інтересів громадян, забезпечення рівності усіх перед законом, невтручання влади у самоорганізацію громадян, підтримки діяльності громадських об'єднань тощо) [7, с. 74-75].

3 огляду на те, що зазначені вище зрізи стосуються, передусім, правової складової процесу розвитку громадянського суспільства та не враховують інші його важливі напрями, вважаємо за потрібне доповнити їх такими зрізами, як:

-соціально-економічний (формування середнього класу як рушійної сили громадянського суспільства і сприятливої для цього економічної політики, створення податкових стимулів для фінансування громадських об'єднань);

-комунікаційно-мобілізаційний (сприяння росту громадської активності й ініціативи через налагодження взаємодії, прямого i зворотного зв'язку влади з громадськістю, запровадження різних форм демократії участі та самоорганізації населення, залучення громадськості до реалізації суспільних рішень, державної та місцевої політики, надання соціальних послуг тощо);

-освітньо-виховний (запровадження громадянської освіти, створення для громадян можливості отримати знання, вміння і навички, необхідні для життя і активної діяльності, формування у громадян та 
представників органів влади відповідної свідомості, цінностей, культури, правил та норм поведінки).

Враховуючи викладене вище, напрями державної підтримки розвитку громадянського суспільства можна звести, насамперед, до: а) забезпечення умов, можливостей, механізмів і засобів для впливу громадян на владу, захисту ними своїх прав й інтересів, задоволення потреб; б) виховання громадян, навчання їх правильно та ефективно використовувати зазначені умови, можливості та механізми; в) впровадження практики належного врядування і підготовку компетентних кадрів в органах влади. Це взаємопов'язані напрями, тому увага влади має бути зосереджена на них одночасно і рівною мірою.

\section{Література:}

1. Габермас Ю. Структурні перетворення у сфері відкритості: дослідження категорії громадянське суспільство. Львів, 2000. 318 с.

2. Громадянське суспільство: політичні та соціально-правові проблеми розвитку: монографія / Г.Ю. Васильєв, В.Д. Воднік, О.В. Волянська та ін.; за ред. М.П. Требіна. Харків, 2013. 536 с.

3. Денисюк М.В. Теоретико-правові засади взаємодії держави та інститутів громадянського суспільства: дис... канд. юрид. наук: 12.00.01. Київ, 2014. 223 с.

4. Зеленько Г.І. Інституціоналізація громадянського суспільства у постсоціалістичних країнах (на прикладі країн вишеградської групи та України): дис. ... доктора політ. наук: 23.00.02. Київ, 2007. 387 с.

5. Костюк Т. Сепаратизм в Україні: ілюзія чи реальна загроза. Політичний менеджмент. 2011. №4. С. 119-125.

6. Піроженко Н.В. Механізми становлення та розвитку соціального партнерства органів публічної влади і неурядових некомерційних організацій: дис. ... канд. наук з держ. упр.: 25.00.02. - Одеса, 2007. $225 \mathrm{c}$.

7. Стеценко С.Г. Громадянське суспільство та соціальна держава: проблеми взаємодії. Право України. 2014. № 4. С. 71-80. 